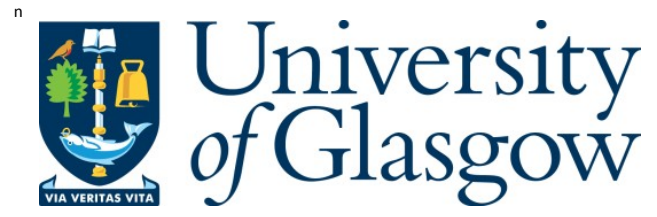

Head, N. (2016) Costly encounters of the empathic kind: a typology. International Theory, 8(1), pp. 171-199.

There may be differences between this version and the published version. $Y$ ou are advised to consult the publisher's version if you wish to cite from it.

http://eprints.gla.ac.uk/112891/

Deposited on: 01 December 2015

Enlighten - R esearch publications by members of the U niversity of Glasgow http://eprints.gla.ac.uk 


\title{
Costly encounters of the empathic kind: a typology
}

\author{
Naomi Head ${ }^{1}$
}

\begin{abstract}
While considerable attention is being accorded to emotions in International Relations, this article seeks to integrate empathy into these interdisciplinary debates. It counters the dominant assumption that empathy tends to be largely benign and beneficial by conceptualising a typology of the costs of empathy. The dimensions of costs addressed are: epistemological, cognitive, emotional, material, and embodied. I argue that these costs are frequently tangible for those who make the ethical-political choice to engage in empathy in situations of conflict and political violence. Drawing on social psychology approaches, empathy is located within a framework of collective narratives, emotions, and social structures shaped by both micro- and macro- political processes. A model of empathy, which acknowledges social influences and the psychological mechanisms through which these influences may be mediated, contributes to a deeper understanding of how politics, psychology, and culture shape empathy and, crucially, helps understand the conditions which may affect the successes, limitations and failures of empathy in the (international) political sphere. The article offers empirical illustrations of the costs of empathy drawing on examples from Israel and Palestine.
\end{abstract}

Key words: Empathy; Emotions; Israel/Palestine; Micro-politics; Narrative; Conflict transformation; Socio-psychological infrastructure

\section{Introduction}

While considerable attention has been accorded to emotions in International Relations (IR) in recent debates, this article seeks to build on the debates on emotion by drawing attention to the questions at stake when we seek to theorise empathy in IR. The $18^{\text {th }}$ century saw the spread of empathy, or sympathy, in novels, plays, and public discourse (Reddy 2009: 306-9). While it may be relatively easy to empathise with characters in a play at the theatre, it is far more challenging to empathise with members of an out-group under conditions of (protracted) conflict. Interpersonal dynamics play an important role at all levels of politics, including in the international sphere where the generation of empathy, trust, mistrust and other 'affective relations' (Pedwell 2014) between states rest, in part, on the complex cognitive and emotional relationships between diplomats, leaders and representatives (Holmes 2013; Yarhi-Milo 2013). As such, the significance of empathy - its

\footnotetext{
${ }^{1}$ Politics, University of Glasgow. Email: Naomi.head@glasgow.ac.uk. Article accepted 9 November 2015.
} 
relations of power, costs, meanings and practices - should not be ignored as the navigation of beliefs, values, interests, and narratives remain as important to the construction of international politics as to national or community politics.

The difficulties faced by 'empathy entrepreneurs' ${ }^{2}$ in particular call for an interrogation of what the costs of engaging in empathy might be in order to understand when actors may engage in empathy and the social and political structures and processes which constrain them. ${ }^{3}$ A framework which acknowledges both social influences and the psychological mechanisms through which these influences may be mediated, contributes to a deeper understanding of how politics, psychology, and culture shape empathy and crucially, therefore, helps understand the conditions which may shape the successes, limitations and failures of empathy in the political sphere. While it may be unsurprising to many within IR that empathy is hard to find in conflicts, it is nonetheless necessary to understand the dynamics which block empathy if it is to be able to contribute to sustainable transformations of conflict through re-humanising the other and providing mutual insights to the other's needs and beliefs as it is often characterised in the conflict resolution literature (Deutsch 2006:65; Broome 1993; Rothman 1992; Galtung 2004; Staub 2011; Cameron, Weatherbed 2014).

In order to elaborate on what the costs of empathy may be and to make the case for the relevance of this for international politics, I make two conceptual links in the argument that follows. First, I draw on the social psychology approach which informs Daniel Bar-Tal's socio-psychological infrastructure $(2007,2013)$. As Herbert Kelman and other social psychologists working on conflict have noted, psychological processes constitute and mediate much of the behaviour located within the international sphere (2007: 62). Bar-Tal's framework offers resources for exploring direct and indirect forms of power which enable and constrain the possibilities for empathy as well as highlighting the group dynamics which are key to generating the costs of empathy. Second, I engage with the sociologicallyinformed debate on micro- and macro- approaches to political processes (Hutchison and Bleiker 2014; Linklater 2014; Ross 2014; Kelman 2007). I contend that the sociopsychological infrastructure creates a normative and emotional climate within and between

\footnotetext{
${ }^{2}$ I am grateful to an anonymous reviewer for suggesting this term.

3 Juanita Elias and Shirin Rai have adopted similar terminology in their call to interrogate the "costs" of violence by focusing on the everyday human, as opposed to just the economic, cost of this [gendered] violence' (2015: 425).
} 
groups and societies setting the background against which the transgression of these norms through empathic behaviour may exact costs at a micro level. While such costs may be 'felt' primarily at the individual level, their connection to social norms, identities, beliefs, and political ideologies also ensures that they are entwined in wider structural and political relations.

The re-framing of IR's discrete 'levels of analysis' as a micro-macro approach to politics ensures that research on empathy is not relegated solely to the interpersonal sphere (and therefore marginalised within IR as a discipline which has traditionally focused on state phenomena) but is imbricated in the structural and agentic relations of both individuals and collectives at all levels. Indeed, as Andrew Ross has noted, 'contemporary microsociologists [suggest] that all structures at the macro-level involve micro-level patterns of action' (2014:35). The challenges faced at a micro level by individuals and communities as a result of the societal norms and structures understood through a socio-psychological framework contribute to an explanation of the failure of empathy to have a wider and more sustained impact at a macro level under conditions of protracted conflict.

The article will set out the relevant conceptual frames for empathy, the sociopsychological infrastructure, and the case for engaging with both micro- and macroprocesses. Having clarified the theoretical framework which facilitated the identification of these costs, the article will propose a typology consisting of five main types of cost: epistemological, cognitive, emotional, material, and embodied. Examples of these types of cost are developed in the final section in relation to the case of Israel and Palestine. Coupled with existing scholarly research on inter-group conflict, the empirical data I collected through interviewing approximately twenty Israelis and Palestinians ${ }^{4}$ working with non-violent approaches to the conflict at the grassroots and civil society level in Israel and the West Bank revealed a number of experiences illustrative of the micro-politics of empathy and the costs identified in the typology. ${ }^{5}$ Focusing on the lived experiences of empathy at a micro-level allows these threads to be woven into a more complex picture of

\footnotetext{
${ }^{4}$ Including Palestinian citizens of Israel and West Bank Palestinians. The small sample size poses obvious limits to more generalised claims, but the consistency of the experiences narrated, coupled with the evidence in the wider literature, draws attention to patterns which raise important questions around the conditions for empathy within conflict.

${ }^{5} \mathrm{~A}$ focus on the costs of empathy experienced by those on all sides is not intended to flatten out the differences between subject positions, to gloss over the asymmetry of the conflict, nor to assume that all Israeli or Palestinians, irrespective of these differences, experience empathy or its absence in the same way.
} 
micro-macro relations of conflict engendered by group dynamics and the sociopsychological infrastructure. ${ }^{6}$ The typology offers a capacity to interrogate how and why empathy is costly in cases of conflict beyond the present empirical focus on Israel and Palestine. A focus on relevant political and psychological dynamics contributes to a stronger understanding of the challenges facing empathy and its entrepreneurs in international politics if empathy is indeed to work for sustainable peace and social justice. ${ }^{7}$

Israel and Palestine is an appropriate case to draw on to support and illustrate a theorisation of the costly dimension of empathy for several reasons. First, the considerable extant research on the narratives of conflict in the region, the emotional, psychological, political and cultural mechanisms through which they are perpetuated, and the consequences this has for social and political relations are all relevant for developing conceptual and analytical approaches for other protracted conflicts in international relations. Second, the extensive inter-disciplinary academic and policy focus on resolution and reconciliation processes that has developed around this conflict frequently recognises the need for empathy - either implicitly or explicitly - but focuses less on theorising its limits and contingencies. Third, the degree to which the conflict is interwoven with the structures, institutions, discourse and policies of international actors draws attention to the need to reconfigure our ways of thinking about levels of analysis in IR given the salience of emotions, empathy and narratives at the micro and macro level for the perpetuation, potential transformation, and analysis of the conflict.

\section{Defining empathy: walking a few miles in the shoes of the other}

Four psychological states have been identified which are helpful for establishing a suite of capacities called empathy and for recognizing the complex relationship between cognition and emotion which characterises empathy (Batson and Ahmad 2009). The cognitive/perceptual states identified are: 1 ) Imagine-self perspective (imagining how one would think and feel in another's situation), and 2) Imagine-other perspective (imagining how another person thinks or feels given his/her situation - also characterised as cognitive

\footnotetext{
${ }^{6}$ See Kelman $(1996,2010)$ for a discussion on the close relationship between micro and macro processes in international conflict resolution from a social psychology perspective.

${ }^{7}$ It is worth noting that the costly nature of empathy does not necessarily make it bad. The psychological pain of empathizing with the enemy may be constructive and even desirable. Any developmental process is likely to be difficult, but the cognitive and emotional challenges posed by the empathic process raise the possibility of positive/transformative outcomes. Thanks to David Traven for comments on this.
} 
perspective-taking). The affective/emotional states identified are: 3) Emotion matching (feeling as another person feels), and 4) Empathic concern (feeling for another person who is in need - this is also commonly characterized in the literature as sympathy) (Batson and Ahmad 2009: 144). These categorisations of cognitive-emotional activities, which fall under the broad umbrella of empathy, also reflect the emergence of distinctions between empathy, compassion/sympathy, and emotional contagion. Emotional contagion is an automatic response to the emotions of others which is experienced at an early stage of human development before babies have learnt to differentiate between themselves and others (Frevert 2011: 150). While sympathy, like compassion, implies a 'pro-social, cooperative and benevolent attitude towards the other person' (Frevert 2011: 178), empathy does not inevitably require any positive regard for the other (White 1984: 9). Indeed, Martha Nussbaum has noted that a torturer may use empathy for "hostile and sadistic ends' (2001: 333).

This broader set of empathic-related capacities can also be defined as the 'art of stepping imaginatively into the shoes of another person, understanding their feelings and perspectives, and using that understanding to guide your actions' (Krznaric 2014: x). This type of definition serves more than one meaning of empathy. It embraces a broader, philosophical, definition of perspective-taking which may be morally neutral and which is essential to all forms of social interaction, whether cooperative or conflictual, as well as empathy in the normative sense which implies some form of positive identification with the feelings of others. It is the latter meaning with which we are currently concerned; while cognitive perspective-taking is largely unavoidable, it does not precipitate the same degree of normative interest in the well-being of others.

The case for focusing on the costs of empathy emerges from the normative narratives of empathy often found in the peacebuilding, development, psychological, and political literatures (Pedwell 2012, 2013; Crawford 2002, 2014; Marlier and Crawford 2013; Staub 2011; Monroe 2012; Kelman 1996, 1999; Nussbaum 2002; Baron-Cohen 2011; Bar-Tal 2013; Halperin, Sharvit, and Gross, 2011; Morrell 2010) which tend to assume that exercising empathy, although far from easy, is largely beneficial in the long-term for the parties involved as it may lead to reconciliation, conflict resolution, deliberative democracy, or practices of global governance. This normative orientation to promoting the well-being of others is captured by Neta Crawford's argument that 'Increasing the capacity for empathy 
is likely one of, if not the most important, routes to peace and justice' (2014: 544). In parallel policy terms, President Barack Obama voiced much the same sentiment in his address to the United Nations General Assembly, when he said in relation to Israel and Palestine that 'the deadlock will only be broken when each side learns to stand in the other's shoes; each side can see the world through the other's eyes' (2011).

This normative approach to empathy seeks to expand the boundaries of our moral concern (Krznaric 2014: xxi), to extend compassion towards vulnerable others, to encourage pro-social behaviour, to contribute to social cohesion, reconciliation and 'humanising' processes, and to develop ethical deliberative capacities (Morrell 2010). This approach usually attributes universal recognition to other human beings as fellow humans (Appiah 2006; Nussbaum 2002; Linklater 2007; Staub 2011) and challenges tendencies to objectify others in order to exclude or act violently against them in some manner. Even Martha Nussbaum, who assigns a neutral value to empathy, recognises that it involves a "basic recognition of another world of experience, and to that extent it is not altogether neutral' (2001: 333). In other words, the failure to recognise the humanity of others is a deeper kind of evil even than empathy used for hostile ends. As Ervin Staub summarises, '[k]nowing adversaries so as to accurately take their perspective, understanding their concerns and needs, and empathizing with them enables people to work on resolving conflict and overcoming hostility' (2011: 328). It is, he suggests, a key component to humanising others (2011). Similarly, mediators Giandomenico Picco and Gabrielle Rifkind have declared that 'empathy - which is not appeasement - is an essential component of the art of peacemaking because entering into the mind of the enemy increases the possibility of resolving conflict' (2014: 7). Empathy is also often accorded a moral dimension, as it articulates a crucial element of an ethics of political community and questions the extent of our moral and ethical obligations to distant and unknown others (Slote 2007; Koehn 1998; Habermas and Dews, 1992: 269). While such a normative and ethical account of empathy is extremely valuable, this literature neglects explicit attention to the costs which attend such empathic behaviour, particularly for empathy entrepreneurs. The aim of this article is to demonstrate how it is frequently costly for those who make the ethical-political choice ${ }^{8}$ to

\footnotetext{
${ }^{8}$ A volunteer for MachsomWatch said that joining the organisation (run by Israeli women who oppose the Occupation, monitor the checkpoints and run tours for Israelis and foreigners in the West Bank and Jerusalem
} 
engage in empathy in situations of conflict and political violence and, in doing so, to develop a typology of costs which has wider applicability for the study of empathy in international politics.

\section{Socio-psychological infrastructure}

I argue that the socio-psychological infrastructure (Bar-Tal 2007; 2013) - the institutionalisation and perpetuation of a collection of shared narratives, memories, emotions, attitudes, and beliefs - may be both an obstacle and an aid to the development of empathic encounters. While intractable conflict and existential threat remain the dominant narrative of a society there is little room for collective empathy to emerge within the discourses of the public sphere and the challenges associated with transgressing these norms of hostility towards others and the associated negative emotions may be high. Conversely, through processes of resolution, reconciliation and political change, shifts in the socio-psychological infrastructure may contribute to a greater capacity for individual and collective empathy. ${ }^{9}$ This framework, which provides the scaffolding for any interpersonal or intergroup encounter in conflict (at a micro- or macro- level), is comprised of three elements: collective memories, an ethos of conflict, and collective emotional orientations (2007: 1435; 2013). ${ }^{10}$ These three elements contribute to the formation and consolidation of a strong social identity that provides individuals with the security, support, sense of belonging, and national coordination necessary to cope with the conflict situation (2007: 1443).

Taking each of these three components in turn, collective memory is constructed through narratives which represent the past as it is remembered, interpreted, and reconstructed by members of society as the history of the group (Bar-Tal 2013: 137). Along with shared societal beliefs, collective memory 'provides an epistemic foundation for the group's belonging, solidarity, existence, [identity,] mobilization, and courses of action'

area) was, for her, 'a political commitment...my penance'. She understood her role and capacity for identification with Palestinians as that of witness. Author interview, 2014.

${ }^{9}$ While empathy always involves individual cognitive-emotional processes, I am using collective empathy to refer to shifts in collective narratives regarding the recognition, legitimization and re-humanisation of the other.

${ }^{10}$ While Bar-Tal's framework is developed with situations of intractable conflict in mind, research on emotions and memory suggest that constellations of shared memories, emotions and beliefs are always operating within and between groups, societies, states, international regimes, organisations, movements and networks (Ross 2014: 35-7). 
(2013: 138). Shared societal beliefs play a key role in organizing, integrating, and orienting the majority of society members through their dominant presence in the public, political, cultural and educational spheres. The themes of societal beliefs, which underpin an ethos of conflict include: 'the justness of one's own goals, opponent delegitimization, selfvictimhood, positive self-image, security, patriotism, unity, and peace' (Bar-Tal 2013: 174-5). These themes loom large in the dominant Israeli and Palestinian narratives (see Hammack 2011) as well as other examples of conflict in international relations.

As some societal beliefs secure a hegemonic position, they serve to underpin the collective emotional orientation of a society. They may evoke emotions, define the lens through which information regarding the conflict and the other is interpreted, and define (il)legitimate ways of expression for those emotions (Bar-Tal 2007: 1435; 2013: 213-4). A collective emotional orientation is shaped in part by the 'feeling rules' embedded within particular societies. Arlie Hochschild noted that a feeling rule denotes which emotions are appropriate or expected in particular situations (von Scheve 2012: 4). Feeling rules are, therefore, 'a subset of prescriptive social norms that...demarcate the intensity, direction, duration, and objects of emotions appropriate in a situation' (von Scheve 2012: 4). Just as social norms guide behaviour, so too feeling rules guide emotions and their regulation. Such normative regulation supports and sustains beliefs about the 'other', justifies violent or aggressive responses in particular situations towards the out-group, and generally serves to shape the emotional perception of the other in ways which align with the needs of societies. The more 'sacred' the belief or identity is to a particular society, the more mobilized the group is likely to be to protect it, the more emotional commitment is likely to circulate within the group and the greater the likelihood of shared negative emotions towards the out-group. Under such circumstances, empathising with the other group's equally sacred beliefs is likely to trigger retribution in some form and/or pressure to conform to the hegemonic belief. Entrenched collective emotional dispositions towards groups, individuals, or symbols are likely to inhibit empathy, as well as creating greater difficulties for empathy entrepreneurs, especially as they may be triggered through socialisation and memory rather than solely through direct experience. ${ }^{11}$

\footnotetext{
${ }^{11}$ Neta Crawford makes a similar argument when she observes that 'emotions are often institutionalized, incorporated, and eventually, deeply embedded in the processes and structures of world politics. The
} 
Much of what blocks the capacity or willingness to empathise with the other in situations of conflict stems from the collective narratives of groups, the membership of 'ingroups' (and associated biases) and the construction of superiority over 'outgroups' and the perceptions attached to these modes of history and social identity (Siniver 2012; Hammack 2011; Bar-Tal 2007, 2013; Maoz, Steinberg, Bar-On and Fakhereldeen 2002; McDoom 2012). Consequently, each group is likely to 'incorporate the historical facts within its own cognitive schema of the conflict' (Rouhana 2004: 42). These master narratives ${ }^{12}$ are important for reflecting on the costs of empathic encounters because they articulate the degree to which such behaviour is likely to challenge societal norms and beliefs.

Recent work in process sociology and IR complements the contributions of social psychology in terms of understanding how emotions may interact with beliefs to shape group identity and behaviour and, therefore, impact our willingness or ability to engage in empathic interactions. Simon Koschut has written that

emotional knowledge forms part of asymmetries of power and status in which 'established' groups secure the compliance of outsiders. Insiders maintain and reproduce a particular self-image of social superiority vis-à-vis outsiders based on group charisma and emotional knowledge (feelings of social superiority/pride). At the same time, established groups persuade outsiders to internalize feelings of social inferiority (shame) through emotional rigidity, stigmatization, and by placing the contact of insiders with outsiders under a taboo (2014: 541).

Such asymmetries of power and status shape which voices get heard and which narratives are accepted or marginalised. Operating not only at a discursive level, such asymmetries also impact on the constitution of political power at an institutional level.

The constitution of empathy, as with emotions, is not reducible to the biological or neuroscientific processes of the individual, as individuals are always embedded in social

institutionalization of emotions is perhaps the key thread that ties the agential aspects of emotions to the structures and processes of world politics' (2013: 122).

${ }^{12}$ Master narratives are intended to be indicative rather than deterministic or homogenising. They highlight the importance of such narratives and the work that they do but they are not intended to construct a binary dichotomy of subject positions. 
contexts. These contexts shape whether empathy is likely to be expressed, how it may be expressed, and by and for whom (Demertzis 2013: 6). Empathy requires that 'we connect the process in the micro-level to the process in the macro-level. So people see that it is not other people that are responsible but me and you and you and you that are creating this dynamic in the conflict' (Interview with Sonnenschein, 2014). This recognition of focused responsibility embraces the complex micro- and macro- dynamics between the beliefs, behaviour, and values of the individual, the structures and discourses of societies, and the policies of governments; all aspects reflected in the socio-psychological infrastructure. The adoption of the distinction between micro and macro politics has increasingly shaped the emotions debates in IR as well as elsewhere. Nicolas Demertzis has noted in relation to the analysis of emotions that

the micro level concerns the intrapersonal dimensions of emotive life, the meso level corresponds to social interaction in groups, institutions, everyday encounters and the emotional dynamic therein, whereas the macro level entails norms, rules, law, traditions and socio-economic structures which provide the 'path dependency' for emotional cultures and social emotions to be formed (2013: 8).

In other words, the multiple layers of emotional life, from the individual to the international, are interlinked. The preceding discussion of the socio-psychological infrastructure demonstrates the significance of the dominant emotional climate, norms and beliefs of society for the formation of a micro-politics of empathy. Making a parallel argument in relation to emotions, Demertzis notes that '[a]s they are distributed in time and space, norms function as an instance of the macro reality; internalized by the subjects qua beliefs and goals they are rendered an instance of microreality' (2013: 8).

Consequently, collective emotional orientations of societies affect not just the decision-making and interpretative processes of individuals but they also animate the policy process through the assessment of threats, the construction of security discourses, decisions on military spending, defense, foreign policy, and so on (Crawford 2013: 123; Saurette 2006). This link between micro- and macro-politics is implicit in Paul Saurette's writings which chart the relationship between perceptions of humiliation as a central 
emotional force of an individual - former President George W. Bush - to humiliation as a structuring dynamic of post-9/11 global politics. Similar arguments with regards to the political status of individually experienced emotions - notably humiliation, betrayal and their often violent consequences - have been made by, among others, Richard Jackson (2014) and Khaled Fattah and K. M. Fierke (2009). Their respective writings on the 'war on terror' demonstrate the way in which master narratives (and collective emotional orientations therein) of the self and other relationship influence and shape the process of identity formation, the personal and political decisions of 'ordinary' people and their leaders, and their propensity for empathy towards out-groups. Individual experiences of humiliation, shame and violence have been interpreted through the lens of broader historical narratives of trauma, betrayal and humiliation and this has shaped the multiple, interdependent and complex layers of intractable conflict that former President Bush called the 'global war on terrorism'. The resulting emotional climate created through the sociopsychological infrastructure creates further barriers to empathy at both the micro and macro levels. The extensive array of existing political, educational, and cultural sociopsychological mechanisms support the wider argument concerning the need to move away from discrete levels of analysis towards an approach which examines how macro- and micro- politics are interwoven. The micro-politics of empathy point to the complex processes through which macro-political structures and ideologies are contested, negotiated and filtered.

\section{A Typology of the costs of empathy: theory and practice}

In line with its oft-cited normative benefits, empathy is often presented as an inhibitor of aggressive behaviour and a contributing factor in preventing people from committing acts of violence against others (Baron-Cohen, 2011; Staub 2011: 327; Moses 1985). As will be clear from the preceding discussion this claim should be mediated by recognising that membership of in-groups and out-groups (and their associated identities) is likely to shape any empathic process. In other words, empathy with fellow members of the in-group - and the consequent strengthening of collective identity - may serve to block or limit the empathy shown towards members of the out-group and contribute to dynamics of conflict. Empathy is not, therefore, an emotion per se, but a process which can trigger a wide range of emotions. Empathy oriented towards fellow members of the in-group as a result of 
'terrorist' actions against them has, for example, triggered negative emotions and justified harmful behaviours - torture, rendition, human rights abuses, targeted killings - towards those perceived to be in out-groups.

It is a widely recognised phenomenon of group dynamics that members of a group may police others within the group. Ron Aminzade and Doug McAdam capture this essential dynamic and it is worth quoting them at length:

all such groups - informal no less than formal - provide bedrock identity and other ontological benefits to their members. The fact that they do affords these groups some considerable leverage with which to shape the actions of those individuals who hope to retain the various solidary benefits that come with group membership. In other words, once the process of "social appropriation" has taken place and the group has committed itself to collective action, anyone resisting the new definition runs the risk of losing the mix of member benefits associated with participation in the group. To the extent that the group, and its associated collective identity, has become an integral part of the individual's life and self-identity, the kind of enduring "affective emotions" mentioned by Jasper (1998), such as fear of rejection and ostracism, can be a powerful force for conformity to the new behavioural and attitudinal requirements of group membership (2001: 37).

This component of group dynamics - whereby some group members police others - clearly speaks to the argument that empathy with members of the out-group, wherein group boundaries, norms, beliefs and identities may be transgressed, could have significant costs. In order to avoid sanctions such as social exclusion, shame or embarrassment, group members are likely to regulate their emotions towards outsiders in order to conform to social expectations. This kind of in-group policing is established through a range of sociopsychological mechanisms, such as boundary activation, outgroup negativity or delegitimization of the other, outgroup homogenization, ingroup solidarity/cohesion and positive self-image (McDoom 2012: 122-3; see Bar-Tal 2013: 25, 175-6). These mechanisms are likely to be triggered in the face of material or symbolic threats. The greater the perception of threat, the greater the need for in-group loyalty and therefore, the higher the 
cost for transgressing collective norms, beliefs and narratives. What is at stake in the argument which follows is what these costs may look like and how they pose obstacles to effective and sustainable conflict transformation.

The ways in which the socio-psychological infrastructure in Israel and Palestine is strengthened are considerable, including: extensive sharing of the beliefs and accompanying emotions widely held by members of society (individuals are socialized with these from an early age); wide and active application of their daily use in individuals' lives through public discourse, social media and mass communication, through oral history, through nationalreligious ceremonies, commemoration, rituals, and symbols; a widespread presence in cultural media, and their frequent appearance in educational materials (Bar-Tal 2007: 1445; Bar-Tal 1998; Pappe 2010; Peled-Elhanan 2012; Bar-On 2001; Caspi and Rubenstein 2012). Extending this line of argument in another context, the socio-psychological infrastructure which shapes the dominant terrorism discourse has similarly been maintained by 'a large assortment of social institutions (the media, academia, security agencies, legal entities, political actors, and so on), an ever-growing set of material and discursive practices of security and control...and a vast array of cultural productions (films, novels, academic outputs, newspaper articles, official reports, laws, regulations, jokes, Web sites, comics, art, theater, and so on)' (Jackson 2015: 2). Where the socio-psychological infrastructure supporting a conflict narrative has been successfully institutionalised, the cost of empathy with members of the out-group is likely to be higher (and the rewards for in-group loyalty correspondingly significant). Empathy is costly, therefore, because power operates through social identities and group dynamics in such a way that it is psychologically and politically difficult for people to empathize with outsiders.

The more effective the socio-psychological infrastructure is, the more challenging it is for individuals who seek to identify with and voice alternative narratives. As Jackson highlights in his discussion of terrorism mythography, when faced with " the dilemma that the serious novelist shares with the ethnographer - the need to empathize with one's subject in order to be true to their tale", the terrorism novelist is bound to conform to the dictates of the [contemporary cultural and political] taboo and avoid at all costs "talking to terrorists"' (2015: 8). Moreover, Sonnenschein noted in a further illustration of sociopsychological control mechanisms that research has shown that 'when there is a peak in the conflict our [Israeli] journalists forget their professional identity and stick to their national 
identity. They speak the voice of the government' (Interview, 2014). Reinforcing these patterns, escalations of violence or crisis points allow 'chosen traumas' embedded in the master narrative to be reactivated in the face of more recent traumatic events and the associated emotions (grief, loss, anger, fear, resentment, hate) and beliefs drawn upon in order to ensure the support of in-group members for the current crisis whilst at the same time further delegitimizing the opponent or out-group (Volkan cited in Bar-Tal 2013: 146). The master narratives in Israel and Palestine demonstrate the ongoing role of the Nakba and the Holocaust as chosen traumas of the Palestinians and Israelis respectively. ${ }^{13}$ Where such traumas - both historical and contemporary - have been deeply written into the emotional fabric of collective memory and political community, they tend to generate narrow and fearful definitions of security and, consequently, to reinforce antagonistic political relations. The activation of socio-psychological mechanisms through narrated trauma engenders further barriers to empathy as the difficulty in challenging the collective narrative increases along with the pressure to remain loyal to the in-group.

The socio-psychological infrastructure effectively reveals considerable political and psychological obstacles to empathy. When the norms, narratives, identities, emotions and beliefs of groups/societies are transgressed by empathy entrepreneurs, I argue that there are often considerable costs to engaging in empathy. Developed as a typology in order to capture multiple dimensions, the table below identifies five types of cost: epistemological; cognitive; emotional; material, and embodied. ${ }^{14}$ The typology not only allows the identification of the specific costs across multiple dimensions of individual experience but it enables direct and indirect relations of power to be traced within and between societies.

\begin{tabular}{|l|l|}
\hline Types of Cost & Forms of expression (examples) \\
\hline Epistemological & Positions of hierarchy \\
& Voices of authority/'expert' knowledge \\
& $\begin{array}{l}\text { Objectivity } \\
\text { Limits of knowledge }\end{array}$ \\
\hline
\end{tabular}

\footnotetext{
${ }^{13}$ Four key themes are identified by Hammack (2011) in the master narrative of Jewish-Israeli identity. These are: 1) historical persecution and victimization of the Jews; 2) existential insecurity; 3 ) the exceptionalism of Jewish Israelis; and, 4) the delegitimization of the Palestinians which, at the extreme end of the spectrum, is characterised by a denial of an indigenous Palestinian identity (2011: 117. Similarly, Hammack identifies four central themes in the master narrative of Palestinian identity: 1) the experience of loss and land dispossession; 2) resistance as a consequence of the perceived injustice of this loss; 3 ) existential insecurity in terms of identity and everyday life in Palestine; and, 4) the delegitimization of Israeli identity (2011: 160-1).

${ }^{14}$ Neither the types nor the examples provided of these costs are claimed to be exhaustive.
} 


\begin{tabular}{|l|l|}
\hline Cognitive & Alienation from in-group/collective \\
& narrative \\
& Rupture or disintegration of individual and \\
& collective identities \\
& Cognitive dissonance \\
& Re-constitution of beliefs, values, identity \\
\hline Emotional & Loneliness/rejection \\
& Social reprobation/social exclusion \\
& Confusion/uncertainty \\
& Guilt \\
& Shame \\
& Fear \\
& Anger \\
& Emotional dissonance \\
\hline Material & Threat of or loss of job security/career \\
& prospects \\
& Loss of power/influence \\
& Harm to reputation/status \\
& Physical violence \\
& Intimidation \\
\hline Embodied & Sweating \\
& Sleeplessness \\
& Discomfort \\
& Vulnerability \\
& Tears \\
& Fatigue \\
\hline
\end{tabular}

Feminist theorists have theorised empathy as an intersubjective epistemology, which moves away from the notion of the autonomous or universal subject (Hemmings 2011; Collins 2000; Sylvester 1994). It is, they suggest, one way of mitigating the forms of representational violence often done through an absence of empathy for the knowledge and experience of the other subject (Hemmings 2011: 201). While not unproblematic, feminist thought highlights an important epistemological point: engaging in empathy may represent a cost in relation to positions and voices of authority, 'expert knowledge', and established intellectual and institutional hierarchies. Empathy requires of its participants whatever their professional status, class, race, or gender - an openness and vulnerability to the ontological and epistemological knowledge of the 'other'. Such openness may disrupt dominant modes of thinking and feeling as it encounters marginalised identities, forms of knowledge, and subaltern narratives. 
While this is by no means necessarily a cost - indeed many would argue it is an asset! - it nonetheless runs counter to an objective or positivist epistemology that has long dominated international relations and political science. Questioning the authority of the speaking or writing academic subject, Jackson argues that 'the professional academic voice is strictly limited in its capacity to convey some realities, some knowledge, some voices' (2015: 13; Dauphinee 2010). Rejecting a clear divide between affective and cognitive modes of empathy also serves to challenge the rationalist paradigm which pre-determines what forms of 'knowing' are possible. Clare Hemmings articulates the empathetic critique of epistemology in two ways; first as recognition of 'feeling as knowing', which draws attention to 'the importance of the researcher or knower as embodied rather than abstracted', and second, 'the importance of moving beyond the subject and towards intersubjective practices and modes of knowing' (2011: 198). Christine Sylvester's feminist epistemology supports this reading as she argues that 'empathetic cooperation [offers] a navigational method of politics at borderlands' through which 'our subjectivities travel to accommodate the new empathies' (1994: 326). Drawing on María Lugones' notion of "world"-travelling (1987), Sylvester's writing emphasises both the uncertainties around knowledge, affect, identity, and subjectivity which empathy may produce and the capacity for empathy and cooperation to enable 'different worlds and ourselves within them' (1994: 326, citing Lugones). Such subjective shifts are likely to unsettle established ideas of self and other.

This epistemological perspective confronts a criticism often voiced amongst recipients of aid and peace-building programmes: the authority and knowledge of the 'expert' aid worker or peacebuilder. Séverine Autesserre highlights the perception of locals that foreign peacebuilders impose their outside knowledge 'in a manner both disrespectful and humiliating' (2014: 103). Reminiscent of colonial structures of power, the perception is that the foreign interveners "know what is best for local people" (2014: 202). Autessere elucidates the structures of inequality that permeate international peacebuilding and the hierarchies established between locals and foreign peacebuilders. The altruistic narrative of being "here to help", adopted by the interveners, enables claims to moral superiority, greater expertise, authority, and greater social capital (2014: 195). Autessere elaborates this imbalance of power in an interview conducted with an experienced peacebuilder: 
No matter how hard Larke and his colleagues tried to use "the most empowering methodologies," the "classic, almost paternalist thinking" that permeates aid efforts "crept into the psychology of everyone". To Larke, this patronizing attitude was rooted in the very fact of being "brought in from the outside with the idea that we are here to help - that people are needy and lack capacity" (2014: 198).

Discounting the knowledge of local people often leads to the pejorative 'othering' of these communities as well. Under such circumstances, the disruptions and shifts implied by epistemological costs of empathy are unlikely to unfold. The epistemological cost of empathy not only underpins the other dimensions of cost in that it represents an individual intellectual, emotional or embodied journey, but it also represents a call for caution to practitioners, peacebuilders, politicians, policy-makers and researchers who represent the knowledge and experience of the other without having undergone the discomfort of travelling towards them, their knowledge, and their worlds. As such, it poses challenges for the frequently hierarchical structures of international conflict resolution, peacebuilding, and policy-making, placing the knowledge and experience of those affected at the core of such work and opening up conversations about (il)legitimate forms of knowledge and their expression.

I argued above that cognition and emotion should be treated as mutually constitutive of empathic processes; while an analytical distinction is helpful for the purposes of the typology, empirically separating these intertwined processes is rarely possible. Alienation from one's own collective narrative is likely, for example, to both evoke and be constituted by emotions of sadness, anger, guilt, shame, and loneliness. Similarly, the deconstruction and reconstruction of individual or collective beliefs and identities is likely to be accompanied by a range of emotions. This process of alienation emerges from a dissonance between the socially expected emotions, beliefs or identity - feeling rules which are institutionalised in the socio-psychological infrastructure, and the actually experienced emotions, beliefs, shifts in values, and so on. Drawing on experiences from Israel and Palestine, the illustrations of a micro-politics of empathy that follow do not adhere strictly to a single type of cost but instead demonstrate these interwoven types as 
consequences of in-group policing dynamics enabled through the framework of the sociopsychological infrastructure. $^{15}$

As the stronger party in an asymmetrical conflict, for some Israelis the most significant cost of engaging in empathy is often a sense of isolation or alienation from the dominant cultural and political Israeli master narrative and the consequent forms of identity disruption or cognitive dissonance which this causes. ${ }^{16}$ The choice to become involved in transformative dialogue work is not a trivial one and may invoke a social, emotional, and material price; being defined as someone who engages with or loves the 'enemy other' 'may close certain social circles, options and contacts for the facilitator who may face rejection and exclusion from those who object to Jewish-Palestinian partnership' (Maoz, Bekerman, Getz Sheftel 2007: 40). Yiftach Ron and Ifat Maoz have written that 'Israeli Jews who have experienced such transformative encounters often find relating to wider Jewish Israeli society more difficult, reporting loneliness and even reprobation, particularly in times of war or crisis [...] They are alienated from the Jewish-Israeli collective ethos and the conflictsupporting master narrative' (2013: 290). ${ }^{17}$ This cognitive and emotional cost was expressed through acknowledgement that encounters with Palestinians and political positions which challenged the Jewish-Israeli master narrative had led to accusations of betrayal or being a 'traitor' by groups within their own communities (Interview with Gvirtz, 2014). ${ }^{18}$ This serves as a kind of threat, a form of in-group policing, which says that 'we do not want you as a part of our society' (Interview with Gvirtz, 2014).

A key cost of engaging in empathy with the Israeli other for Palestinians includes accusations of normalization which is one of most powerful narratives within the contemporary Palestinian political climate and which, at times, imposes a form of 'identity

\footnotetext{
${ }^{15}$ Recognising the role played by in-group dynamics is not intended to deny the plurality of internal group dynamics, narratives, and beliefs in Israeli or Palestinian society but rather to highlight the psychological function of groups.

${ }^{16}$ Jackson also recognises the dissonance caused by empathy through fiction: 'I wanted the affective qualities of the narrative to challenge the reader to re-evaluate and rethink their attitudes and beliefs about the motives of a terrorist and the nature of terrorism, in large part by humanizing the "terrorist" and generating a kind of dissonance - causing empathy with his life story, grievances, and aims (if not his methods)' (2015: 14, emphasis added).

${ }^{17}$ There is a risk that if over-generalised this assumption may veil the recognition of extant alternative minority narratives within the Israeli public sphere. In so doing it would risk representing a dialogue around the 'costs' of empathy in terms which grant too much significance to the structures of the state and the sociopsychological infrastructure and insufficient importance to agency and counter-narratives, articulated through the myriad acts of resistance or transformation which are present within Israeli and Palestinian societies.

${ }^{18}$ Other Palestinian and Israeli NGO leaders interviewed also reported similar issues (2014).
} 
policing' (Abu Nimer and Lazarus 2007:22; Interviews with Helou, Dajani, 2014). An example of this is the experience of Professor Mohammed Dajani, formerly head of the American Studies Department at Al Quds University until his resignation in June 2014, who took a group of twenty-seven Palestinians students to visit Auschwitz as part of an educational experience designed to develop understanding of the Holocaust and to teach tolerance and empathy. The project, "Hearts of Flesh - Not Stone" was organized by the Friedrich Schiller University in Jena, Germany and funded by the German Research Foundation. As part of the same project, Israeli students from Ben-Gurion University of the Negev also visited the Dheishe refugee camp in Bethlehem to learn about the Nakba. Following the trip, Professor Dajani resigned as the result of a months-long campaign of threats, intimidation and extreme criticism within the Palestinian media and wider community (Kalman 2014; Lazareva 2014; Black 2014; Booth 2014). Dajani identifies multiple types of cost, notably material and emotional, as the price for engaging in empathy as a practice of resistance to both the Israeli occupation and to the Palestinian collective narrative around normalisation:

There have been very personal attacks against me and all my academic career has been wiped out and all my accomplishments in the service of the Palestinian cause has been crossed out and I have been labelled...a traitor and I am betraying the cause. ...And then there are threats against my life...instead of this trip becoming an educational trip for students who have been raised up...in an environment of ignorance and an environment of denial of the Holocaust...an educational trip becomes a political trip, and I personally become a target, not only in terms of labelling and character assassination but also in terms of personal safety and personal security (Interview 2014).

Dajani considered that these attacks were intended to close down the political space for dialogue and alternative political futures. Here we see ways in which in-group policing has functioned to generate particular costs to engaging in empathy. Such dynamics, Dajani indicates, are intended to prevent deviation from the Palestinian dominant narrative around normalization and to prevent the development of reconciliation processes between Israelis 
and Palestinians, thus affecting not just individuals but also national and international political processes:

I think the idea is to terrorise professors and teachers and intellectuals ... If you break from that collective version that has in the last sixty years caused us one disaster after another, and made us lose one opportunity after the other, making us only get deeper and deeper in the abyss then you have either to listen ... to their way of thinking or you are a traitor to their cause (Interview 2014).

Dajani's experience clearly underlines the argument that contesting the Palestinian narrative of anti-normalisation by facilitating empathic relations with Israelis is associated with particular types of costs. Imposing such costs through in-group policing maintains the particular collective narratives and emotional orientations that underpin the ethos of conflict and the political status quo.

Similar issues were faced by participants in the Peace Research Institute in the Middle East (PRIME) dual narrative project which brought Israeli and Palestinian teachers together between 2002 and 2009 to develop and teach a history text comprising of two, parallel, narratives for events across the last century for two nations. Some Palestinian teachers faced pressure not to participate from anti-normalisation critics and those who sought to bring the dual narrative approach into their classrooms were not permitted to do so (Interview with Naveh, 2014). Israeli participants who sought to adopt the dual narrative approach in their classroom were subject to formal cautions by the Israeli Ministry of Education (Interview with Naveh, 2014). Such consequences represent material costs in terms of job security as well as the cognitive and emotional costs triggered by perceptions of threat, fear, and vulnerability.

Further cognitive and emotional costs are encountered by individuals - including Dajani's students - when we consider the dissonance created by the transition from the equality of the safe space of the face-to-face encounter in dialogue workshops to the ongoing (and asymmetrical) reality met with by both Jewish Israelis and Palestinians in the social and political world (Interview with Palestinian East Jerusalemite, 2013; Hammack 2011: 312). This involves the psychological experience of having one's salient social identity 
challenged within the construct of the workshop, peace camp, or program, only to return home and re-encounter the narrative of the other either directly or indirectly (through the perceptions of others) as a threat to one's identity. Both Palestinians and Israelis acknowledged encountering a lack of understanding, resentment, criticism, and charges of normalisation from family and friends which not infrequently resulted in participation in such encounters remaining hidden from their own communities (Interviews with Kalifon, 2014, Helou, 2014, Naveh, 2014, Israeli NGO leader, 2014). Such informal forms of pressure reflect the dominant narratives and the ethos of conflict in both societies. The degree of cognitive and emotional dissonance that this may create, as the result of the disruption of the master narrative, speaks to the efficacy of the socio-psychological infrastructure and the difficulties of transgressing the societal beliefs of the in-group. ${ }^{19}$

Another example of the costly nature of empathy emerges in the intergroup work of the School for Peace between Israelis and Palestinians. Recounted in the analysis of Sonnenschein et al (2010), a dialogue encounter by Israelis with a Palestinian group of participants with a strong sense of their own identity posed significant epistemological, cognitive and emotional disruption to the Israeli Jewish image of themselves, their image of the Palestinian other, as well as the coherence and perceived superiority of their collective identity, knowledge, and narrative. Sonnenschein et al write:

They [the Jewish group] felt that the information presented by the Palestinian group contradicted their positive moral self-image and they felt that their selfimage was threatened. [...] Thus, this stage of the process is characterised by internal emotional turmoil, featuring confusion, uneasiness, and pangs of conscience. Self-respect is eroded as the collective moral self-image deteriorates (2010: 55).

Underpinning the emotional and cognitive dissonance articulated in this example is the epistemological challenge posed by the encounter to the authority and knowledge of the Jewish-Israeli narrative.

\footnotetext{
${ }^{19}$ It is not difficult to imagine such dissonance also encountered in the international realm by diplomats or negotiators in situations of conflict.
} 
While Bar-Tal suggests a number of formal control mechanisms exercised by the state which serve to consolidate and embed these collective narratives and beliefs, he also recognises that informal forms of pressure to conform may also be exercised by individual members against those who seek to believe or present information which contradicts the dominant socio-psychological repertoire of conflict (2007: 1445). The preceding examples have highlighted a number of ways in which these informal forms of pressure function. Further evidence of formal and informal socio-psychological mechanisms emerged in the public debate over the condemnation of Israeli Jews who voiced empathy for Gazans in the July-August 2014 war or who went further and opposed the war and Israeli policy. Such expressions were largely deemed illegitimate by both the wider public on social media sites and by socially privileged actors such as government ministers, politicians, and university administrations in public statements, as they challenged the dominant Jewish-Israeli narrative, the collective emotional orientation of Jewish-Israeli society and the ethos of conflict which was strengthened in a time of crisis. The social and political status of many of these actors ensured that certain empathic narratives - and their speakers - have been marginalised. Encountering multiple types of costs - cognitive, emotional, material and embodied - through the dynamics of in-group policing, those uttering them have been intimidated, accused of betrayal, treason, being anti-Israel, socially alienated, and the victims of violence and incitements to violence. They have risked loss of status, reputation, and influence within their own communities (Hari 2010; Levy and Levac 2014; Prusher 2014; Arad 2014; Pappe 2010; Carlstrom 2014; Fraser 2014; Ronen 2014; Kashti 2014). When undertaken through overtly political channels activities expressing empathy have also led to monitoring and questioning by the Israeli security services (Hass 2010).

Last but not least, I want to turn to the reflections of Zoughbi Zoughbi, Director of the Wi'am Center in Bethlehem, whose words highlight how empathy may be mapped onto the body:

It's really a process. It needs to be sweating, it needs to be armed from your toe to your head with morals. It needs to be worked with conscious[ness] and conscience. It needs a kind of evaluation of yourself - read the history of yourself. ... It needs sleeplessness at night. ... It's not easy, even on the daily level (Interview 2014). 
This embodied dimension of empathy is deeply evocative and it highlights the need for further research on the embodied issues surrounding empathy conceptualised as a costly encounter. Building on Lugones' writings, Hemmings highlights the importance of 'discomfort' in the process of 'travelling towards the other' (2011: 200). This bodily discomfort is also traceable through the previous illustrations of material, emotional and cognitive costs. While psychological and phenomenological approaches have engaged with embodied empathy, this has largely been done in the context of the relational experience between the self and the other. As such the question of intersubjectivity focuses on the different levels of connecting and merging with the other's bodily experience (Finlay 2005; Dekeyser, Elliott, Leijssen 2009). Indeed, Maurice Merleau-Ponty argued that 'it is precisely my body which perceives the body of another person' (cited in Finlay 2005: 276). This focus, whilst important for empathy, does not attend to the embodied experience of the self. Here it is not so much the listener's appreciation of or ability to connect with the embodied experience of the other (a core element of psychotherapy and Rogerian counseling) that is at stake but rather the meaning attributed to these embodied experiences by those living them. Clare Hemmings has referred to ways in which the "breakdown of empathy produces a crisis mediated instead by prioritizing "bodily knowledge" (2011:197). While empathy triggers forms of bodily knowledge, this is not limited to the failures or the breakdown of empathy. Indeed, I would suggest that forms of bodily knowledge may be an inherent dimension to all forms of empathy. This remains an area for further research, yet it is likely that all forms of empathy will write itself on the body in both physiological and psychological terms.

\section{Conclusions}

Whilst exposure to contested and disruptive narratives of the other may serve to trigger a re-examination of the language and terminology used by all parties to conflict, limit moral exclusion and elicit greater moral concern through the reconstruction of one's social identity, empathy - to 'walk a few miles in the shoes of the other' - is a demanding psychological and embodied experience which has the potential to trigger the disruption of one's identity in multiple ways. Drawing on a range of empirical examples from Israel and Palestine, I have sought to demonstrate how the socio-psychological infrastructure of societies in conflict creates significant costs to engaging in empathy. Group dynamics and 
social identities function in ways that make it both politically and psychologically difficult for individuals or groups to empathise with outsiders and, in particular, those portrayed historically and discursively as 'enemies'. The stronger the socio-psychological infrastructure is the higher the costs may be for empathy entrepreneurs.

More broadly in international politics, the macro-level socio-psychological infrastructure sets the background against which empathic behaviour may exact costs at a micro level. The perpetuation of the collective emotional orientation, ethos of conflict, and collective memories at a micro-level through effective in-group policing in turn feeds the wider reinforcement and iteration of macro-discourses around conflict and security. We can trace the relationship between the costs experienced at the micro-level by individuals to the continuation of broader policies, narratives, and beliefs which reinforce and perpetuate the conflict. The development of the typology highlights not only the types of costs exacted from empathy entrepreneurs but raises broader questions around the production and maintenance of conflict in international politics through the acceptance or contestation of selected narratives of conflict by political elites. Following the events of $9 / 11$, former U.S. secretary of defense Robert McNamara and James Blight argued for

The Empathy Imperative. The West, led by the United States, must seek by all possible means to increase its understanding of the history, culture, religion, motives, and attitudes of those who have declared themselves to be its adversaries. This effort should begin by developing empathy toward the Islamic fundamentalists, specifically those groups allied with, or sympathetic to, the international terrorist network known as al-Qaeda. Empathy does not imply sympathy or agreement; it does imply curiosity, leading to deeper understanding of an adversary's mindset, as a prerequisite to resolving differences and eliminating threats to peace and security (McNamara and Blight 2003: 234).

The epistemological costs of empathy are of particular significance for policy-makers and political leaders as the forms and limits of knowledge they bring attention to pose a challenge to the hierarchies of political elites, to understandings of national interests and identity, to established relations of power and (in)equality, and to a reluctance to reveal 
vulnerability or uncertainty within domestic or international politics. As Maria Mälksoo writes, each state 'wishes to secure its being as a certain sort of being; to guarantee its cohesiveness in order to reduce the fundamental unpredictability of the surrounding environment and its own vulnerability vis-à-vis other political actors' (2015: 4). The ontological security of states to which Mälksoo is referring is problematised by the epistemological costs of empathy. Empathy unravels our established notions of security through understanding the histories, narratives, beliefs, and emotions of others. Empathy exposes a need to reconfigure self-other relations more reflexively in international relations; it requires policy-makers to break habitual patterns of othering, to make space to reflect on the consequences of our actions and beliefs on others as well as the potential interpretations of our actions. Empathy requires a willingness to engage with subaltern narratives and to unsettle the established representations of other states and collective actors. If policy makers and practitioners are interested in making empathy work for peace, then more attention needs to be paid to both analysing potential costs in specific contexts of conflict and seeking to remove these barriers to empathy. In addition, greater awareness of the potential costs of failing to empathise is required, as McNamara has cogently articulated in reflections on his experiences of war (McNamara and Blight 2003; Morris 2003). These empathic practices call for reflecting on the design and implementation of conflict interventions, peace-building programmes, and foreign policy by actors at both the macro and micro levels.

That there remains room for optimism, however, can be seen in the micro-politics of many civil society organisations working in situations of violence that place empathy at their core. Examples of such sites of hope in Israel and Palestine include the grassroots organisations, Parents Circle - Families Forum, Combatants for Peace, and the School for Peace (Neve Shalom-Wahat al-Salam) as well as myriad expressions of individual and collective empathy voiced during the Gaza 2014 war. Hope, as defined by Halperin et al, can lead to 'higher cognitive processing and requires setting goals [including yearning for relief from negative conditions]; planning how to achieve them; use of imagery, creativity, cognitive flexibility, mental exploration of novel situations, and even risk taking' (2008: 235). Echoing a similar set of cognitive skills to empathy, hope as an emotion provides a counterweight to the costs through the creative and committed activities of organisations and individuals such as those mentioned above which can contribute to (an admittedly 
marginalised) collective emotional orientation. That empathy may be costly does not prevent agents - at grassroots or elite levels - identifying with counter-narratives that look for the transformation of conflict. That this work often tugs against the tides of public opinion - and the socio-psychological infrastructure - is equally evident. As Ted Hopf notes, any 'efforts to change have first to overcome the power of habitual perceptions, emotions and practices' (2010: 540). Perhaps against the odds, empathy entrepreneurs - as agents of social and political change - develop modes of resistance to the individual and collective biases perpetuated by the socio-psychological infrastructure.

\section{Acknowledgements}

Thanks go to the Carnegie Trust for the Universities of Scotland for funding that supported this research and the Kenyon Institute for hosting my stay in Jerusalem. Thanks for their insightful comments on earlier drafts go to Ty Solomon, Karin Fierke, Vivienne MatthiesBoon, Katherine Allison, Volha Piotukh, David Traven, the participants at ECPR in Glasgow 2014, and the members of the HINT cluster at the University of Glasgow and the ICCS in Birmingham where this paper was first presented. I am grateful for the robust and constructive comments provided by three anonymous reviewers and the journal editors.

\section{References}

Aminzade, Ron and Doug McAdam. 'Emotions and Contentious Politics', in Ronald R. Aminzade, Jack A. Goldstone, Doug McAdam, Elizabeth J. Perry, William H. Sewell, Jr., Sidney Tarrow, Charles Tilly, Silence and Voice in the Study of Contentious Politics, (Cambridge: Cambridge University Press, 2001)

Abu Nimer, Mohammed and Ned Lazarus. 'The Peacebuilder's Paradox and the Dynamics of Dialogue: A Psychosocial Portrait of Israeli-Palestinian Encounter', in Judy Kuriansky (ed.), Beyond Bullets and Bombs: Grassroots Peacebuilding between Israelis and Palestinians (Westport: Praeger 2007)

Appiah, Kwame Anthony. Cosmopolitanism: Ethics in a World of Strangers, (New York: W. W. Norton, 2006)

Arad, Dafna. 'Israeli artists opposing the war come under attack on social media networks', Haaretz, 22 July 2014: http://www.haaretz.com/news/diplomacy-defense/.premium1.606482 (accessed 22 July 2014) 
Autesserre, Séverine. Peaceland: Conflict Resolution and the Everyday Politics of International Intervention, (Cambridge: Cambridge University Press, 2014)

Bar-On, Daniel. 'The Silence of Psychologists', Political Psychology, 22(2), 2001, pp.331-345

Bar-Tal, Daniel. 'The Rocky Road Toward Peace: Beliefs on Conflict in Israeli Textbooks', Journal of Peace Research, 35(6), 1998, pp. 723-42.

Bar-Tal, Daniel. 'Sociopsychological Foundations of Intractable Conflicts', American Behavioral Scientist, 50(11), 2007, pp.1430-1453

Bar-Tal, Daniel, Neta Oren, Rafi Nets-Zehngut. 'Sociopsychological analysis of conflictsupporting narratives: A general framework', Journal of Peace Research, 51(5), 2014, pp.662-675

Bar-Tal, Daniel. Intractable Conflicts: Socio-Psychological Foundations and Dynamics, (Cambridge: Cambridge University Press, 2013)

Baron-Cohen, Simon. Zero Degrees of Empathy, (London: Penguin, 2011)

Batson, C. D. and Nadia Ahmad. 'Using Empathy to Improve Intergroup Attitudes and Relations', Social Issues and Policy Review, 3(1), 2009, pp.141-177

Black, lan. 'Palestinian professor: no regrets over taking students to Auschwitz', The Guardian, 13 June 2014, http://www.theguardian.com/world/2014/jun/13/palestinianprofessor-resigns-students-auschwitz

Bleiker, Roland and Emma Hutchison. 'Fear no more: emotions and world politics', Review of International Studies, 34, 2008, pp.115-35

Booth, William. 'Palestinian university students' trip to Auschwitz causes uproar', Washington Post, 12 April 2014

Broome, Benjamin J. 'Managing differences in conflict resolution: the role of relational empathy', in Dennis J. D. Sandole and Hugo van der Merwe (eds.), Conflict Resolution Theory and Practice, (Manchester: Manchester University Press, 1993)

Cameron, Lynne and Simon Weatherbed. Empathy Dynamic in Conflict Transformation: A Manual, (Open University/ESRC: 2014)

Carlstrom, Gregg. 'The Death of Sympathy: How Israeli hawks intimidated and silenced the last remnants of the anti-war left', Foreign Policy, 5 August 2014

Caspi, Dan and Danny Rubenstein. 'The Wallkeepers: Monitoring the Israeli-Arab Conflict', in Daniel Bar-Tal and Izhak Schnell (eds.), The Impacts of Lasting Occupation: Lessons from Israeli Society (Oxford: Oxford University Press, 2012) 
Collins, Patricia Hill. Black Feminist Thought: Knowledge, Consciousness, and the Politics of Empowerment (2000)

Crawford, Neta C. 'The Passion of World Politics', International Security, 24(4), 2000, pp.11656

Crawford, Neta, C. Argument and Change in World Politics: Ethics, Decolonization and Humanitarian Intervention, (Cambridge: Cambridge University Press, 2002)

Crawford, Neta, C. 'Emotions and international security: Cave! Hic Libido', Critical Studies on Security, 1:1, 2013, pp.121-123

Crawford, Neta, C. 'Institutionalizing passion in world politics: fear and empathy', International Theory, 6(3), 2014, pp.535-557

Dauphinee, Elizabeth. 'The ethics of autoethnography', Review of International Studies, 36(3), 2010, pp.799-818

Dekeyser, Mathias, Robert Elliott, and Mia Leijssen. 'Empathy in Pschotherapy: Dialogue and Embodied Understanding', in Jean Decety and William Ickes (eds.). The Social Neuroscience of Empathy (Cambridge, Mass.: MIT Press, 2009)

Demertzis, Nicolas. 'Introduction: Theorizing the Emotions-Politics Nexus', in Demertzis (ed.) Emotions in Politics: The Affect Dimension in Political Tension (Basingstoke: Palgrave Macmillan, 2013)

Deutsch, Morton. 'Justice and Conflict', in Morton Deutsch, Peter T. Coleman and Eric C. Marcus (eds.), The Handbook of Conflict Resolution: Theory and Practice, $2^{\text {nd }}$. Edn., (San Francisco: Jossey-Bass, 2006)

Elias, Juanita and Shiring Rai. 'The Everday Gendered Political Economy of Violence', Politics and Gender, 11(2), 2015, pp.424-429

Fattah, Khaled and K. M. Fierke, 'A Clash of Emotions: The Politics of Humiliation and Political Violence in the Middle East', European Journal of International Relations, 15(1), 2009, pp.67-93

Finlay, Linda. "Reflexive Embodied Empathy': A Phenomenology of Participant-Researcher Intersubjectivity', The Humanistic Psychologist, 33(4), pp.271-292

Fraser, Giles. 'Against the war: the movement that dare not speak its name in Israel', The Guardian, 7 August 2014

Frevert, Ute. Emotions in History: Lost and Found (Budapest: Central European University Press, 2011 
Galtung, Johan: Transcend and Transform: An Introduction to Conflict Work (London: Pluto Press, 2004)

Habermas, Jürgen and Peter Dews. Habermas: Autonomy and Solidarity, (London: Verso, 1992)

Halperin, E., K. Sharvit, and J. J. Gross. 'Emotions and emotion regulation in conflicts'. In Daniel Bar-Tal (ed.), Intergroup Conflicts and their resolution: A social psychological perspective, (New York: Psychology Press, 2011).

Halperin, Eran, Daniel Bar-Tal, Rafi Nets-Zehngut and Erga Drori. 'Emotions in Conflict: Correlates of Fear and Hope in the Israeli-Jewish Society', Peace and Conflict: Journal of Peace Psychology, 14, 2008, pp.233-258

Hammack, Phillip L. Narrative and the Politics of Identity: The Cultural Psychology of Israeli and Palestinian Youth (Oxford: Oxford University Press, 2011)

Hari, Johann. 'Is Gideon Levy the most hated man in Israel or just the most heroic?' The Independent, 24 September 2010

Hass, Amira. 'Conscientious Objector Yonatan Shapira Questioned by Shin Bet', Haaretz, 20 July 2010

Hemmings, Clare. Why Stories Matter: The Political Grammar of Feminist Theory (London: Duke University Press, 2011)

Hemmings, Clare. 'Affective solidarity: Feminist reflexivity and political transformation', Feminist Theory, 12(2), 2012, pp. 147-161

Holmes, Marcus. 'The Force of Face-to-Face Diplomacy: Mirror Neurons and the Problem of Intentions', International Organization, 67(4), 2013, pp 829-861

Hopf, Ted. 'The logic of habit in International Relations', European Journal of International Relations, 16(4), 2010, pp.539-561

Hutchison, Emma and Roland Bleiker, 'Theorizing emotions in world politics', International Theory, 6(3), 2014, pp.491-514

Jackson, Richard. 'Terrorism, Taboo, and Discursive Resistance: The Agonistic Potential of the Terrorism Novel', International Studies Review, 2015 (online first), pp.1-18

Kalman, Matthew. 'Palestinan professor who took students to Auschwitz responds to threats', Haaretz, 10 April 2014

Kashti, Or. 'Israeli university rebukes professor who expressed sympathy for both Israeli, Gazan victims', Haaretz, 29 July 2014 
Kelman, Herbert C. 'Interactive Problem-Solving: Changing Political Culture in the Pursuit of Conflict Resolution', Peace and Conflict: Journal of Peace Psychology, 16, 2010, pp.389-413

Kelman, Herbert C. 'Social-Psychological Dimensions of International Conflict', in I. William Zartman (ed.), Peacemaking in International Conflict: Methods and Techniques, (Washington D. C.: United States Institute of Peace, 2007)

Kelman, Herbert C. 'Transforming the Relationship between Former Enemies: A SocialPsychological Analysis', in R. L. Rothstein (ed.), After Peace: Resistance and Resilience, (London: Lynne Rienner, 1999)

Kelman, Herbert C. 'Negotiation as Interactive Problem Solving', International Negotiation, 1, 1996, pp.99-123

Koehn, Daryl. Rethinking Feminist Ethics: care, trust and empathy, (London: Routledge, 1998)

Koschut, Simon. 'Emotional (security) communities: the significance of emotion norms in inter-allied conflict management', Review of International Studies, 40(3), 2014, pp.533-558

Krznaric, Roman. Empathy: A Handbook for Revolution, (Croydon: Random House, 2014)

Lazareva, Inna. 'Palestinian professor resigns over students' trip to Auschwitz', The Telegraph, 10 June 2014

Levy, Gideon and Alex Levac. 'Dark Days: Why Gideon Levy isn't going back to Ashkelon anytime soon', Haaretz, 19 July, 2014

Linklater, Andrew. 'Anger and World Politics: How Collective Emotions Shift Over Time', International Theory, 6(3), 2014, pp.574-78

Linklater, Andrew. Critical Theory and World Politics (Abingdon: Routledge, 2007)

Lugones, Maria. 'Playfulness, "World"-Travelling, and Loving Perception', Hypatia, 2(2), 1987, pp.3-19

Mälksoo, Maria. 'Memory must be defended': Beyond the politics of mnemonical security', Security Dialogue, 2015, pp.1-17

Maoz, Ifat, Shoshana Steinberg, Dan Bar-On and Mueen Fakhereldeen. 'The Dialogue between the 'Self' and the 'Other': A Process Analysis of Palestinian-Jewish Encounters in Israel', Human Relations, 55(8), 2002, pp. 931-962

Maoz, Ifat, Zvi Bekerman, and Maya Getz Sheftel. 'Can talking to each other really make a difference? Perspectives on reconciliation-aimed dialogues in the conflict between IsraeliJews and Palestinians', in Judy Kuriansky (ed.) Beyond Bullets and Bombs: Grassroots Peacebuilding between Israelis and Palestinians (Westport: Praeger 2007) 
Marlier, Grant and Neta C. Crawford. 'Incomplete and Imperfect Institutionalization of Empathy and Altruism in the 'Responsibility to Protect' Doctrine', Global Responsibility to Protect, 5, 2013, pp.397-422

McDoom, Omar Shahabudin. 'The psychology of threat in intergroup conflict: emotions, rationality, and opportunity in the Rwandan genocide', International Security, 37 (2), 2012, pp. $119-155$

McNamara, Robert and James G. Blight. Wilson's Ghost: Reducing the risk of conflict, killing, and catastrophe in the 21st century (2nd. ed.). (New York: Public Affairs, 2003)

Monroe, Kirstin Renwick, Ethics in an Age of Terror and Genocide, (Princeton: Princeton University Press, 2012)

Morrell, Michael E. Empathy and Democracy: Feeling, Thinking, and Deliberation, (Pennsylvania: Pennsylvania State University Press, 2010)

Morris, Errol. The fog of war: Eleven lessons from the life of Robert S. McNamara [Motion picture]. United States: Sony Pictures Classics, 2003

Moses, Rafael. 'Empathy and Dis-empathy in Political Conflict', Political Psychology, 6(1), 1985, pp.135-139

Nussbaum, Martha. Upheavals of Thought: The Intelligence of Emotions, (Cambridge:

Cambridge University Press, 2001)

Nussbaum, Martha, and Joshua Cohen (eds.). For Love of Country? (Boston: Beacon Press) 2002 [1996]

Obama, Barack. Remarks by President Obama in Address to the United Nations General Assembly, September 21, 2011, https://www.whitehouse.gov/the-pressoffice/2011/09/21/remarks-president-obama-address-united-nations-general-assembly

Pappe, Ilan. Out of the Frame: The Struggle for Academic Freedom in Israel (London: Pluto Press, 2010)

Pedwell, Carolyn. 'Affective (self-)transformations: Empathy, neoliberalism and international development', Feminist Theory, 13(2), 2012, pp.163-179

Pedwell, Carolyn. 'Affect at the margins: Alternative empathies in 'A Small Place', Emotion, Space and Society, 8, 2013, pp.18-26

Pedwell, Carolyn. Affective Relations: The Transnational Politics of Empathy, (Basingstoke: Palgrave Macmillan, 2014)

Peled-Elhanan, Nurit. Palestine in Israeli Schoolbooks: Ideology and Propaganda in Education (London: I. B. Tauris, 2012) 
Prusher, Illene. 'In Israel or Gaza, declaring sympathy for the other side is a no-go zone', Haaretz, 20 July 2014

Reddy, William. 'Historical Research on the Self and Emotions', Emotion Review, 1(4), 2009, pp.302-315

Rifkind, Gabrielle and Giandomenico Picco. The Fog of Peace: The Human Face of Conflict Resolution (London: I. B. Tauris, 2014)

Rifkin, Jeremy. The Empathic Civilization: The Race to Global Consciousness in a World in Crisis, (New York: Penguin, 2009)

Ron, Yiftach and Ifat Maoz. 'Dangerous stories: Encountering narratives of the other in the Israeli-Palestinian conflict', Peace and Conflict: Journal of Peace Psychology, 19(3), 2013, pp.281-294

Ronen, Gil. 'MK says Haaretz's Levy is a traitor', Israel National News, 3 August 2014, http://www.israelnationalnews.com/News/News.aspx/183678\#.VcDFnflwzTo

Rothman, Jay. From Confrontation to Cooperation: Resolving Ethnic and Regional Conflict, (London: SAGE, 1992)

Rouhana, Nadim N. 'Group Identity and Power Asymmetry in Reconciliation Processes: The Israeli-Palestinian Case', Peace and Conflict: Journal of Peace Psychology, 10(1), 2004, pp.33-52

Ross, Andrew A. G.. Mixed Emotions: Beyond Fear and Hatred in International Conflict, (Chicago: Chicago University Press, 2014

Saurette, Paul. 'You dissin' me? Humiliation and post 9/11 global politics', Review of International Studies, 32(3), 2006, pp.495-522

Siniver, Asaf. 'Israeli Identities and the Politics of Threat: A Constructivist Interpretation', Ethnopolitics, 11(1), 2012, pp.24-42

Slote, Michael. The Ethics of Care and Empathy (Abingdon: Routledge, 2007)

Sonnenschein, Nava, Zvi Bekerman, Gabriel Horenczyk. 'Threat and the Majority Identity', Group Dynamics: Theory, Research, and Practice, 14(1), 2010, pp.47-65

Staub, Ervin. Overcoming Evil: Genocide, Violent Conflict, and Terrorism, (Oxford: Oxford University Press, 2011)

Sylvester, Christine. 'Empathetic Cooperation: A Feminist Method for IR', Millennium: Journal of International Studies, 23(2), 1994, pp.315-34 
Von Scheve, Christian. 'Emotion regulation and emotion work: two sides of the same coin?' Frontiers in Psychology, 3, 2012, pp.1-10

White, Ralph K. Fearful Warriors: A Psychological Profile of U.S.-Soviet Relations (New York: The Free Press, 1984)

Yarhi-Milo, Karen. 'Tying Hands Behind Closed Doors: The Logic and Practice of Secret Reassurance', Security Studies, 22(3), 2013, pp.405-435

\section{Author interviews}

Interview with Palestinian East Jerusalemite, 6 September 2013

Interview with Nava Sonnenschein, Director of Neve Shalom-Wahat al-Salam (School for Peace), 4 May 2014

Interview with Zoughbi Zoughbi, Director of the Wi'am Center for Conflict Resolution, 5 May 2014

Interview with Eyal Naveh, Tel Aviv University, 20 May 2014

Interview with Amos Gvirtz, Activist, Kibbutz Shefayim, 14 May 2014

Interview with Yovav Kalifon, Tiyul Rihla, 9 May, 2014

Interview with Israeli NGO leader, 9 May 2014

Interview with Ina Friedman, MachsomWatch, 13 May 2014

Interview with Ahmed Helou, Tiyul Rihla, 19 May 2014

Interview with Mohammed Dajani, Wasatia, 21 May 2014 